\title{
A genealogy of political theory: a polemic
}

\section{James Alexander}

Department of Political Science, Bilkent University, 06800 Ankara, Turkey. jalexand@bilkent.edu.tr

\begin{abstract}
Here is a sketch of a genealogy of political theory for the last century. This is a genealogy in Nietzsche's sense: therefore, neither unhistorical taxonomy, nor a history of political theory as it is written by historians, but a typology in time. Four types of modern political theory are distinguished. These are called, with some justification, positive, normative, third way and sceptical political theory. Seen from the vantage of the twenty-first century, they form an instructive sequence, emerging as a series of reactions to the canonical political theory that was established in the universities in the late nineteenth century. None of the four should be excluded from our conception of what political theory has been, though most of them, when seen genealogically, reveal their defects more clearly than they do when treated purely theoretically. Since this is a sceptical finding, the genealogy is a polemic against the first three types of modern political theory in favour of the last.

Contemporary Political Theory (2019) 18, 402-423. https://doi.org/10.1057/s41296-018-0275-7; published online 20 November 2018
\end{abstract}

Keywords: political theory; canonical; positive; normative; third way; sceptical

As everyone knows, political theory is protean. Much current academic writing is written within the framework of one type of political theory, or perhaps criticises one type from the vantage point of another; but I see very few attempts to see the subject as a whole. This is one such attempt.

Before I begin I should say something about the approach I take since it is an unusual one. No one should mistake the following for a scholarly history. This is not history as a historian would write it, where adequate attention is paid to variation, contingency, discontinuity (even though I see history that way myself, and would certainly like to read that sort of history about this subject). Nor is it written in a purely theoretical spirit: I am not attempting an exhaustive classification or sketch of ideal types. Instead, I am trying to steer a course between excessive simplification and abstraction on the one hand and excessive complication and recognition of contingency on the other. I do this because I am interested in both history and philosophy, and do not want to neglect one for the 
other, as is still far too common. Above all, I do it because I think there is no other way to see the subject in its entirety. The story is meant to be vivid and suggestive.

The argument of this article is not an exact logical scheme. Nor is it chronology. It is a genealogy: that is, an account of the subject which has a loose flow of logic and a loose flow of chronology to justify not only the fact I distinguish four modern types of political theory from each other but also to justify the fact that they are best understood in one particular order because of their successive emergence from an original comprehensive type. I shall call the four types of political theory, with some justification, positive, normative, third way, and sceptical political theory, and I shall call the original type of political theory, the one found in the nineteenth century, canonical political theory. The chronology begins with the fact that canonical political theory was totalising, and that, in breaking away from it, or trying to resolve its contradictions, successive partial political theories emerged as reactions against it and each other. The logic, for what it is worth, is that positive theory only recognises one type of theory, normative theory recognises two, third way theory wants to reconcile the two in a third or subvert the two by offering a third as an alternative, while sceptical political theory prefers 'none of the above', hence is in a sense a 'fourth way' theory. But the relation between these four is not meant to be logical or chronological. It is meant to be conjectural, hypothetical, genealogical.

By 'genealogy' I mean history written with an obvious axe to grind against something in the history it recalls, and against the standard histories which celebrate that something. Many writers influenced by Nietzsche and Foucault use this term. Sometimes it is used as if it is no different from history itself. Alexander Nehemas (1985, p. 246) claims that, for Nietzsche, 'genealogy is history, correctly practised'. Whether one agrees with Nehemas or not depends on what one means by 'correct' (cf. Geuss, 1999, p. 17; Lane, 2012, p. 80). But surely the point is that while most history displays in sometimes vague or vexed form the consecrations or desecrations of the particular historian (of course modified by the academic and professional necessity of a perfectly reasonable pretence to objectivity), genealogy is a type of history which deliberately and consciously desecrates an element of that history - using history to carry out the desecration. It is a history which puts itself into a critical relation to the histories which have so far been told by historicising history more than it has been historicised before. It is always critical, and sometimes polemical. Even commentators sympathetic to Nietzsche often overlook the fact that the subtitle of The Genealogy of Morality was A Polemic (Lane, 2012, for instance, does not mention this). For present purposes, I am taking genealogy to be, by definition (so to speak, since, of course it is part of genealogy that the historian is hostile to at least some and quite possibly all definitions) a history that is a polemic against standard histories and that uses historicity as its polemical weapon. To use Mark Bevir's definition, genealogy is 'an expression of a radical historicism' which embraces 'nominalism, contingency and contestability' and so 
is opposed to 'appeals to transcendental truths' and therefore, of course, opposed to histories which depend on the view that any unhistorical truth has any validity (Bevir, 2008, p. 273). Genealogy, so defined, may not necessarily be polemical, but it often is, originally always was, and perhaps should be.

\section{Canonical Political Theory}

This genealogy begins with what may seem a controversial assumption. This is that all modern forms of political theory are successive fragmentations of and restorations of lost parts of a canonical political theory which was established in universities in the late nineteenth century. I shall not defend this assumption, but I shall use it as a starting point. This canonical political theory was not superior in clarity to what came afterwards: but it was a totality, even if incoherent, and the entire engagement of understanding it sought was something that was endangered with every successive adjustment of the meaning of political theory. The proof of this claim is found in the fact that every adjustment required further adjustment to be made later on. The story of these adjustments is the genealogy sketched in this article.

By canonical political theory I mean the entire tradition of famous writings from Plato and Aristotle through Augustine and Aquinas, Machiavelli and Hobbes, Montesquieu and Rousseau, Bentham and Kant, Hegel and Mill (though not yet Marx) - which were collected together in a canon at the end of the nineteenth century by teachers in universities who sought authority for the novel subject of politics. Some famous textbooks were published, initially out of lectures: for instance, in Oxford and Cambridge, T.H. Green's Principles of Political Obligation, J.R. Seeley's Introduction to Political Science, Henry Sidgwick's Elements of Politics. To put it simply, here there was an entire sense of a subject derived from reflection on politics in relation to a collection of great works, which, because of the emphatically progressive view of human history which was common to almost all thinkers in the mid-to-late nineteenth century (of course including Marx), could be seen as a historical canon of increasingly authoritative theories. This progressive mode of thinking has often been studied (see, for example, Burrow, 1966). It existed outside the universities, of course, but what is decisive here is its incorporation into the academic study of politics. Bevir has usefully called this mode of thought 'developmental historicism' (2008, p. 276).

The overwhelming sense of historical development meant that there was no clear distinction as yet between 'political science', 'political theory' or 'political philosophy'. The study of politics was not exact, by twentieth-century standards, because it ranged easily from historical reference to philosophical argument to normative suggestion to practical relevance. Anyone who doubts what I am saying should consult any book written about politics in the nineteenth century. The major 
point is that the unity of the study of politics came from the suggestion that political progress made the entire canon of political writings relevant to the contemporary study of politics.

Our genealogy begins because the centre could not hold. Developmental historicism unravelled because the story of progress encouraged some thinkers to suggest that if our theories were increasingly authoritative through time then the authority of our theories now owed nothing to the canon but only to our present understanding: that, in fact, whatever was useful from older theories could be abstracted and incorporated into newer theories. This line of thought is clearly evident in Seeley's lectures. It was a line which become commoner as theorists became conscious that crisis rendered the history of civilisation discontinuous. The genealogical twist was that in favouring the modern over the antique, the most advanced developmental historicist could go so far as to justify the dismissal of everything historical for the sake of the completely modern - and scientific.

It is this which is the point of origin for our genealogy: for what happened was that the historical canon raised questions it could not answer. By the end of the nineteenth century, historians began to suggest that the canonical writers should be studied historically. The corollary was that they could no longer be considered a useful foundation for the contemporary study of actual politics (Collini et al. 1983) The thinkers who struggled to liberate the study of politics from the canon were the originators of modern political science. The subject matter of this science was politics, meaning actual political activities and processes. As such, it was firmly distinguished from the old classical or canonical political theory. It was ahistorical, so not only did it reject historicism: it rejected any sense of debt to the canon, and it also rejected what was later called the normative element in political theory. Older political theories had almost always included explicit or implicit suggestions about how society ought to be. The new political science rejected this. The abstemiousness of political science was what made it distinctive. When, half a century later, political science was fully established, the president of the American Political Science Association declared (Almond, 1966, p. 871): 'Classical political theory is more a political sociology and psychology and a normative political theory than it is a theory of the political process'. Political science was a theory of the political process only.

The establishment of political science was only the beginning of the genealogy sketched here. For, later, political science would later find itself challenged by normative theories of politics of the sort which were commonly found in the canon, and even later by immanentist theories of politics and the 'radical historicism' of which the genealogy evident in this essay is an instance. 


\section{Positive Political Theory}

At the beginning of the twentieth century, the question was how to make the study of politics an actual study of politics. The answer was to separate out the strictly scientific part of canonical political theory and call it political science. At first this excluded political theory, though eventually political scientists were to realise that they, too, were theorists. While canonical political theory was dominant, 'political science' meant all or any approaches, past or present, to the understanding of politics. It was not meaningfully distinct from political theory or even what we would now call the history of political theory. But during the early decades of the twentieth century, it came to mean a scientific approach, in the present, to the understanding of politics. In this form, it was distinguished from 'political theory', which was understood to be all or any approaches, found in the canon, to the understanding of politics. So for a time political theory was identified with the history of political theory, while political science had nothing to do with theory. However, as we shall see, from the middle of the twentieth century onwards political science would come to mean a scientific approach which was in some sense recognised to be theoretical. At this point, political theory would firmly be distinguished from its history, so that political theory focused again on the present, and the distinction between political theory and political science again became a problem.

Political science is a science which, as we currently know it, America has bestowed on the world (Adcock et al. 2007). Of course political scientists elsewhere also distrusted the classical political theory. The canon which had been established was full of antiquated discussions. It prevented political science from being properly scientific. It distracted political scientists with accounts of the ideal state. And even when it dealt with actual politics, it tended to see it in terms of formal utterances, as found in constitutions, treaties, and laws. But it was in America that there was full liberation from the old traditions. Arthur Bentley published The Process of Government in 1908. In time this book was to be held up as the ideal for a political science which studied actual political behaviour. After the first world war the schools at Chicago and Columbia under Charles Merriam and Harold Lasswell led the new movement. At Harvard, A. Lawrence Lowell continued to write in the older, more patrician, manner. But V.O. Key, Gabriel Almond and Seymour Martin Lipset, alongside Lasswell, extended the hegemony of the new political science for the next three or four decades (Berndtson, 1987). Positivist and empirical, it became now known as 'behaviouralism' and, as such, and still in reaction to the canonical political theory, it was explicitly hostile to 'theory' - which was still associated with historical irrelevance and philosophical ideals. Behaviouralists supposed that there were discoverable uniformities in human behaviour which could be confirmed by empirical tests. They were 
preoccupied with the acquisition and analysis of data. They supposed that the understanding of political behaviour, if scientific enough, would enable predictions to be made about the future of politics.

Yet this sort of assumption, by the middle decades of the twentieth century, was now accompanied by a sense that political science was not without its own theory, and that, in fact, if it were to be capable of achieving anything profound in the way of political understanding, it would have to become theoretically conscious, capable of a more sophisticated sense of the difficulties of saying anything about the world. (Easton, 1991, p. 42.) This is when what I call positive political theory came into existence: the consciousness that political science was necessarily theoretical. Theory understood this way had a fairly narrow meaning. It meant, as Pendleton Herring put it in 1953, 'a conceptual scheme for the analysis and ordering of the empirical behaviour' (quoted in Easton, p. 189). It was an instrument, a tool. It included hypothetical explanations of how some aspect of politics worked. It could take the form of propositions, schemes, models. It generalised. It quantified. It explained processes. It sometimes explained causality. It sometimes enabled the prediction of future outcomes. It was, above all, theory in the sense of a theorem: it was theory for use, as measured by how well it enabled the scientist to capture some aspect of politics.

As theoretical self-consciousness increased, new named forms of study emerged: on the one hand, 'systems analysis' and 'new institutionalism', which were empirical and inductive, and, on the other, after the 1950s, 'game theory' and 'rational choice theory', which were deductive. Admittedly, only the game and rational choice theorists ever called themselves 'positive political theorists', but the truth is that all of these theorists, whether inductive or deductive, were positive. ${ }^{1}$ What united them was their acceptance of the distinction between is and ought. They were concerned with the is of politics, not the ought. They lacked any interest in any question of the was of politics. For some time these three categories of is, ought, and was were fundamental. In the 1960s, the American Political Science Association distinguished theorists according to whether they were empirical, normative or historical (Wolin, 1969, p. 1062).

The standard political science still sees itself as empirical half a century later. Almond was prescient in 1966 when he predicted that the use of quantitative methods, the use of the new research technology, sample surveys, rigorous logical methods, sociological, psychological, and anthropological theory, large-scale research undertakings, research grants, team research, surely are here to stay' (Almond, 1966, p. 869). But political science never really managed to make theory anything other than a tool of quantitative generalisation. Almond also noticed that 'political theorists [were] searching for an explanatory, predictive and manipulative political theory' (p. 872). He hoped for a theory which would 'enable us to move from empirical relationships to normative judgements' (pp. 876-877). But, as we shall see, the establishment of normative political theory within the university as a 
separate branch of study after the 1960s indicated the failure of this particular aspiration.

Some critical voices warned political scientists about the limits of this positive political theory. Some said it had not shown us much about politics because of excessive abstraction. Other said it had concealed its normative commitments or ideological bias behind a language of science. For instance, Hans J. Morgenthau pointed out that the quantitative method could only be applied to 'those types of political behaviour which by their very nature lend themselves to a certain measure of quantification, such as voting' (1955, p. 442). Sheldon Wolin claimed that political science often failed to recognise that its subject was politics. It instead generated 'unpolitical theories shaped by the desire to explain certain forms of nonpolitical phenomena': that is, theories which shared 'the same uncritical - and therefore untheoretical - assumptions of the prevailing political ideology'. Such theories could offer no guidance about what should be done about politics (1969, p. 1063). Commenting on later, more sophisticated, theories, Donald Green and Ian Shapiro were equally damning: 'Hypotheses are formulated in empirically intractable ways; evidence is selected and tested in a biased fashion; conclusions are drawn without serious attention to competing explanations; empirical attention and discordant facts are often either ignore or circumvented by way of post hoc alterations to deductive arguments ... data no longer test theories; instead, theories continually impeach and elude data'. They asked, 'What have we learned about politics?', and answered: 'Exceedingly little' (1994, pp. 6, 182).

Other critics noticed that what had been of value in the canonical political theory had been lost. Almond was aware of 'nostalgia for the great tradition of political theory' (1966, p. 874). David Ricci contrasted the older and newer theories of politics and found the newer ones wanting (Ricci, 1984). And even David Easton (1991, pp. 46-47) admitted that political science was 'shot through with ideology', and that its 'false objectivity' was so striking that the older 'impressionistic methods [had] regained some plausibility'. Others, like John Gunnell (1987, p. 160) and Ronald Beiner (2014, p. 233) came to ask for 'heroic' or 'epic' theories of politics, that is, for theories with recognisably canonical roots. Many agreed that positive political theory lacked self-consciousness about its own assumptions, values and commitments - which, Wolin (1969, p. 1073) noted, 'usually turn[ed] out to be fragments of some almost-forgotten "normative" or "traditional" theory'. It has remained hegemonic in the academic study of politics, but it was exposed on its theoretical front. And this is why some theorists began to suggest in the 1960s that an alternative was necessary.

In sum, what I am calling positive political theory emerged out of a sense that political science, though it rejected much of the canonical political theory, was itself theoretical. It studied politics scientifically, had two major forms: inductive (e.g. behaviouralism, new institutionalism) and deductive (e.g. rational choice, game theory). It concerned the is of politics, and ignored the ought. But it 
sometimes seemed excessively abstract, unselfconscious about its own assumptions, as well as unimaginative and unrevealing about actual politics. In addition, it left to one side much of what had been done in the old canonical political theory.

The question was how to engage more positively with the older tradition of political philosophy, how to restore theoretical sophistication, and how to generate theories which would enable criticisms of actual politics to be made, while not threatening the achievement of positive political theory. The answer was through normative political theory.

\section{Normative Political Theory}

As I have said, political scientists seldom called themselves positive political theorists, though that is what they were. Their dominance of the academic study of politics and their desire to avoid 'theory' of the sort found in canonical political theory meant that the status of all other forms of political study was very low. By the 1950s and 1960s, there was much talk of the 'death of political theory'. Brian Barry (1996, pp. 537-538) later wrote:

When Peter Laslett [in 1956] made the much-quoted assertion that 'political philosophy is dead', he explained that what he had in mind was the absence of contributions to a line of thinkers in English that he took to run 'from Hobbes to Bosanquet'. Richard Tuck has recently written on similar lines of 'the absence of major works of political philosophy, of a more or less familiar kind, between Sidgwick and Rawls'... Nobody until Rawls produced anything that represented a continuation of the canon of political thought, as traditionally conceived.

This was a standard claim in the last half century: that there was a normative tradition of thought which was ruptured in the late nineteenth century. This claim has little historical value: the older canonical political theory was not only normative. But it made sense to those who wanted normative political theory to be established alongside positive political theory. As Timothy Kaufman-Osborn puts it, there was a 'defensive effort to affirm the integrity of forms of intellectual endeavour dismissed or declared defunct by the proponents of behaviouralism' (2010, p. 659). In retrospect, it is fairly clear that the 'death of political theory' was a story told to justify the restoration of a part of the canonical political theory which had been lost.

Normative political theory was named in the 1960s or 1970s for a type of political theorising which had been existed a century before but now required naming in order to defend its territory against political science. It was a reaction against positive political theory. It brought back a discussion of the standards, rules, principles, and values that positive political theory ignored. Normative political 
theory was concerned with ideals, values and standards, intuitions, principles and argument. It threw up theories which 'make claims on us: they command, oblige, recommend, or guide' (Korsgaard, 1996, p. 8). Normative political theory sought a ground, perhaps a metaphysical ground, though more commonly a constructed ground, not so much objective as intersubjective, a ground we could agree on, or establish by consensus, as a condition of our engaging with each other politically. It used the high language of rights, justice, equality and liberty. It tended to avoid power and government. If it turned its attention to the actual world, it did so through the medium of law. It flourished, therefore, at the point where political theory met moral or legal theory. It had almost no economic or sociological content. It supposed that political order was best established through the sort of institutions and constitutions that John Rawls called the 'basic structure'. The practical ideal of such political theory was that normative standards should be imposed on everyone through legislation.

This was a restoration of the part of the canonical political theory which had been concerned with the ideal state. But what should be understood clearly is that its return was permitted not because it subverted positive political theory but because it offered itself as a correlative to it (Grant, 2003). There was a division of labour. Whereas positive political theorists had concerned themselves with the $i s$ of politics and had ignored the ought (as well as the was), normative political theorists accepted the distinction, but reversed the value judgement, and so concerned themselves with the ought of politics. This is why the positive political theorists, after some reflection, were willing to tolerate normative political theory as an element of academic political enquiry. The normativists did not threaten the positive political theorists on their own territory. So, for a time, sanctioned by the political scientists (who mostly still preferred to avoid the ambiguous word 'theory'), normative political theory laid claim to the entire inheritance of political theory. The view that political theory - or political philosophy - was no more and no less than normative political theory was taken for granted in most books written on the subject in the last decades of the twentieth century (see, for example, Kymlicka, 2002; Wolff, 2015; Swift, 2013, the first editions of which were published in 1990, 1996 and 2001, respectively). If there is one figure who was associated with the establishment of normative political theory alongside positive political theory it was Rawls.

Rawls's Theory of Justice set the terms of the debate to which Michael Walzer, G.A. Cohen, Michael Sandel, Amartya Sen were to contribute thereafter. Consider the titles of Walzer's Spheres of Justice (1983), Cohen's Rescuing Justice and Equality (2008), Sen's Idea of Justice (2009), Sandel's Justice: What's the Right Thing To Do? (2010). Everyone who worked in political theory had to become familiar with the great range of Rawlsian stratagems, the thought experiment of an 'original position', the practical proposal of an 'overlapping consensus', and, above all, the theoretical via media offered by 'reflective equilibrium' - 'when someone 
has carefully considered alternative conceptions of justice and the force of various arguments for them' in order to bring rival convictions, principles and judgements into some sort of compromise (Rawls, 2001, p. 31). Barry wrote that 'A Theory of Justice is the watershed that divides the past from the present' (1990, p. lxix). Despite the emergence of other forms of political theory, normative political theory is still largely hegemonic within what is called 'political theory'. For some theorists, the genealogy could stop here, with concessions made to criticism where necessary.

Normative political theory has received much criticism, though normative political theorists have usually only responded to criticism when answers to the criticism can be generated from within normative political theory. Some critics have said that normativists existed in an elevated world of moral ideals and thought experiments and thus ignored politics as it really is. Sandel famously commented: 'Rawls' theory is doubly hypothetical. It imagines an event that never really happened, involving the sorts of being who never really existed' (1982, p. 105). Michael Oakeshott was even pithier: 'The notion of setting up an association ex nihilo, like inventing a game, is absurd' (1999, p. 163). Radicals found it even more objectionable. They said that normative political theory ignored its own political nature. They argued that, although it recognised the significance of values, it supposed too simply that these values could be considered in the abstract, apart from actual political commitments. Though normative political theory enabled theorists to be critical of actual political orders, they could not be critical of their own ideological commitments, since they refused to acknowledge that these too were just as ideological (Geuss, 2009; Mouffe, 2005; Anderson, 2005). One major response to these criticisms has been to claim that without normative political theory there can be no 'corrective to the contingencies of political power' (Kelly, 2005, p. 107). A more subtle response, in the writings of T.M. Scanlon, Derek Parfit and others, has been to restate older arguments in a less exposed though even more recondite form (for a summary, see Ashford and Mulgan, 2012).

In sum, normative political theory was a reaction against positive political theory in defence of the ought of politics. It coexisted alongside positive political theory, because it accepted the distinction between is and ought, and dealt only with the latter. It involved the consideration of standards, rules, principles and values: including the values which positive political theory could only take for granted. Yet, in its search for an ideal theory, it was criticised for being too abstract and remote from actual politics, and too idealistic in assuming that consensus was possible, that politics could be reduced to ethics, and that theorists could work directly with legislators and avoid politics as such.

The question was how to make political theory more conscious of the elements of the canonical political theory which remained forgotten, such as a historical sense of politics and thought about politics, the primacy of politics itself (as opposed to the primacy of ethics or law), and the ubiquity of political ideology and 
commitment. The answer was through some alternative political theory, a third way political theory.

\section{Third Way Political Theory}

It is fair to say that the first two categories of positive and normative theory emerged in America. But the inspiration for the breaking of the modus vivendi between positive and normative theory came not from American but a miscellany of European sources: Nietzschean, Marxist, Weberian, Schmittian, Heideggerian, Foucauldian, and so on: though, of course, this happened as much in America as in Europe, since émigrés from Europe perpetuated lines of thought in America which could never be reduced either to positive or normative political theory. Again, in the face of the establishment of normative political theory some major theorists looked back to the canonical political theory for ways to restore some elements which seemed to have been forgotten. The major claim was that what had been forgotten was politics itself.

These theorists were what I call third way theorists simply because what they sought was some form of theory which refused to accept the convenient but misleading distinction between is and ought which enabled positive and normative to divide the study of politics in two. Third way political theory is a convenient term $^{2}$ for the variety of ways different theorists tried to overcome the duality of the first two categories (Knight and Johnson, 2015). The important point was that it was overcome for the sake of action and not only contemplation. It was observed that many classical political theorists had been engaged in the politics of their time: a historical point which was emphasised by historians of political thought such as Quentin Skinner, John Pocock and others. The corollary was that political theory even now was to tell us, in Lenin's famous phrase, what should be done about politics. Third way political theory owed a debt to some of the epic theorists of the mid-twentieth century, especially those émigrés like Leo Strauss, Hannah Arendt, Eric Voegelin, Hans Morgenthau, Theodor Adorno, Max Horkheimer and others, who wrote about political theory in a way which refused to ignore the history of their own subject, as well as those, like György Lukacs and Louis Althusser, who had attempted to keep a Marxist tradition alive. A few decades after Rawls, these great exemplars - as well as earlier ones like Machiavelli, Locke, Marx and Nietzsche - had been used by Harvey Mansfield, Sheldon Wolin, Jürgen Habermas, Judith Shklar, John Dunn, Bernard Williams, Ernesto Laclau, Bonnie Honig, Richard Bernstein, Fred Dallmayr, William E. Connolly, Jeremy Waldron, Jacques Rancière, Alain Badiou, Slavoj Žižek and many others to suggest a myriad of ways in which political theory should be saved from the normative tradition.

Third way political theory may look like an incoherent class of incommensurable theories. But all these theorists insisted that political theory is political, not only in 
the sense of having politics as its object but in the sense of being conditioned by and perhaps even constituted by politics. They sought a 'political political theory' (Waldron, 2013). For them politics could not be 'an objective datum, or even invariant, of universal experience' (Badiou, 2005, p. 10). Instead the theorist had to fully recognise his or her own partiality, bias, ideological commitment, 'strong sense of political engagement' (Dryzek et al. 2009, p. 67). They should see politics as constituted by unresolvable conflict (Mouffe, 2005, p. 105). ${ }^{3}$ Third way political theory involved a willingness to see politics in more than one way at once. It refused to let politics be depoliticised or domesticated. Instead politics was seen 'as consisting of practices of settlement and unsettlement, of dispute and administration, or extraordinary events or foundings and mundane maintenances' (Honig, 1993 , p. 205). It was often radical, though how radical it could be varied, as we shall see. Sometimes it called itself realistic - suggesting in a word that positive political theory and normative political theory (though it was more concerned with the second of these) had not been realistic (Galston, 2010). It refused to distinguish sharply between a positive theory and a normative theory, suggesting instead that theory had to incorporate elements of both positive description and classification and normative argument and suggestion (Geuss, 2009, p. 16). Needless to say, this 'realism' was not the realism of positive political scientists, who had treated theory, at most, as only part of the armoury of the theorist: it was the realism of those who thought that theories were part of reality. And what I am suggesting is that third way political theory can be understood as a coherent movement once we see it as a genealogical reaction, or set of reactions, to the modus vivendi established between positive and normative political theory in and around the 1970s.

Third way political theory emerged in two or three main forms. The first form accepted normative political theory as it is, but said that we need some way of bridging the gap between normative political theory and actual politics, by relating the two in order to generate a third form of theory which would be more adequately political. The second form, more critical of normative theory, said that we needed an alternative characterisation of politics. A third form - if it can be fully distinguished from the second - said that the point is not to characterise politics as it is, but to theorise the politics which is the appropriate radical answer to the systematic operations of governmental rule which have usurped the proper meaning of politics and which have been sublimated in an almost academic political writing until now.

The first form sought a 'non-ideal' theory to bridge the 'ideal' theories of the normative theorists and actual politics. The second went further and suggested that politics is simply not the way the positive and normative political theorists have seen it: so that an adequate recognition of the multiplicity, rivalry and antagonism of views in politics required a better political theory than a mere bridge between old theories. The third went even further, taking such a negative view of the older theories as symptoms of a false political consciousness that they said that the role 
of a proper political theory was to theorise the rupture of the order associated with that false consciousness.

These three forms of third way theory were increasingly radical. Loosely speaking, if we cast around, we could say that Amartya Sen, Michael Walzer, David Miller, Adam Swift worked within the frame of the first type; Mouffe, Honig. the second; and Rancière, Badiou, Žižek the third. Be that as it may, ${ }^{4}$ the first type of theorist certainly looked for a system which would still include normative political theory, but improve it, by making it more realistic; the second wanted to replace normative political theory with something more realistic and adequately political; and the third - again, if we distinguish it from the second ${ }^{5}-$ went beyond any concern with being realistic for the sake of being adequately political even if this took theory into realms of paradox and obscurity about what Žižek called the 'event', the sort of rupture which would bring conventional politics to an end (Žižek, 2014). There was much polemic between these positions; though it is interesting to observe that third way political theorists generally only ever criticised theorists less radical than themselves and ignored those more radical than themselves.

All third way political theorists took seriously Raymond Geuss's suggestion (2009, p. 97) that 'if you want to think about politics, think first about power'. Why? Foucault (2008, p. 304) gave the reason: 'The juridical structure of power always comes after the event or fact of power itself'. But third way political theorists divided depending according to whether they thought, as Foucault and Geuss did, that one should therefore focus only on power and not justice, since justice reduces to power, or thought, as Waldron (2013) and many others did, that there are 'two tasks' for political theory, one of which was to reflect on justice, as normative political theorists did, and the other of which was to reflect on power.

In sum, third way political theory has been the source of most of theoretical novelty in academic political theory in the last decade or so. It has not existed for long enough to have received serious criticism. But I think we can say that third way political theory has sought a more political type of political theory. It has emphasised power as an element of politics and emphasised the fact that theory must be political, in the sense that it has commitments in and engagements with actual politics, so the relation between theory and practice is not a secondary but a primary question. It has varied according to whether the emphasis on power subverts the normative emphasis on justice or adds something to the normative emphasis on justice, yet, I have suggested, it has three major forms, since third way political theory may seek to relate normative theory and actual politics, may propose an alternative vision of politics, or may theorise a radical rupture with any established order. It has suffered from a variety of disorders yet to be fully identified, such as a continual insinuation of liberal or radical ideals into its theories, as well as, depending on the particular variety of third way political theory, excessive theoretical compromise on the one hand and problems of paradox 
and obscurity on the other. It is, in its myriad of forms, now highly influential, and certainly is at the point where it expects to transform normative political theory once and for all.

It is at this point that further criticism is possible. The question is whether political theory of this sort can avoid lapsing into an endless variety of political commitments which will soon bring to an end the capacity of political theory to be a site of unitary engagement. The answer, I suggest, is 'Yes', and therefore requires a turn to sceptical political theory.

\section{Sceptical Political Theory}

The fourth type of theory is, in short, 'none of the above'. It is not yet clearly established in the literature. Or, rather, one sees it if one looks for it. But there is no question that most political theorists are committed to the first, second, or third types of political theory, and that when they refer to 'political theory' they refer to their own type of political theory as if it is uncontroversial. The fourth type of theory insists on controversy. For it is sceptical. Scepticism in the ancient world was the view that whoever has considered any proposition has so far found that the counter to that proposition has as much warrant as the original proposition. Instead of trying to force the judgement by adopting one proposition and ignoring the other, the sceptic discovers there is warrant for thinking both propositions equally possible - this is called epoche - and that having thought he or she achieves mental tranquillity - this is called ataraxia. It is absolutely fundamental to the original Pyrrhonian scepticism that the sceptic does not hold his view about the equal truth of contradictory propositions dogmatically: on the contrary, it is, or, rather, has been so far, a continually fresh finding. This clearly means that the idea is not to produce 'theorems' but instead 'to theorise' (Oakeshott, 2004, pp. 391-392). Now, by sceptical political theory I am not referring to a universal scepticism, if it even be a coherent position: I am referring to scepticism about this theory, that theory, even my own theory, where it is a political theory.

Theory, for the sceptical political theorist, is the activity of theorising about politics, and not the developing of theorems about politics, or, for that matter, the proposing of normative theories about politics. For the sceptical political theorist, unlike the third way political theorist, political theory is not a type of theorising which is fundamentally conditioned by politics but is a type of theorising, unpolitical in nature, which takes politics as its object. Therefore, and crucially, the sceptical political theorist is able to question politics: it is not taken to be a condition of his or her understanding but as something open to criticism (Oakeshott, 2004, pp. 397-398). Sceptical political theory is sceptical not because it is sceptical in some everyday sense about politics (though it may be); it is sceptical because it assumes theorising is endless, and the endlessness of theorising

(c) 2018 Springer Nature Limited. 1470-8914 Contemporary Political Theory Vol. 18, 3, 402-423 
is limited here by the concern to theorise about politics. Unlike the other three types of political theory a sceptical political theory allows one to ask whether or not politics matters, whether it is derivative from something else, what sense it makes when seen in different contexts, economic, religious, legal, historical. Of these words, the word 'historical' is perhaps the most important for reasons I have already suggested in the introduction.

Sceptical political theory has existed in the interstices of much writing in the last century, especially where political theory has refused to discard its history and has, indeed, retained an urgent sense of history. It is clearly allied to the 'radical historicism' which Bevir suggests is behind any sort of genealogical approach. It is found clearly stated in writers like Oakeshott and Maurice Cowling - in Oakeshott in a more or less pure form, and in Cowling in a form which was, as it was not for Oakeshott, compatible with a defence of Christianity (Cowling, 1963, 2001). It is evident in places in the writings of Carl Schmitt, R.G. Collingwood, Hannah Arendt, Richard Rorty, John Dunn, Raymond Geuss and Frank Ankersmit, though some of these writers also had third way elements in their thought. ${ }^{6}$ Sceptical political theory is a form of theory, or, better, theorising, in which one considers all possible arguments, and weighs each in turn, without committing oneself politically to any one of them. (That is of course the ideal: in practice, one's own commitment is also something to be subjected to criticism.) Though it is a philosophical position, it has survived only where a sense of history has survived. History has offered scepticism many weapons: an entire history of weapons. I don't think it is any surprise that modern academic history and modern academic scepticism are so often found together. It is the sceptic who has the highest regard for the history of political theory. Positive political theorists struggle to make anything out of history: they can only make sense of it if it comes in the form of data, something which can be modelled. They reject the canon of political theory almost entirely. Normative political theorists are interested in the canon of political theory in so far as it supplies them with arguments. Third way political theorists are more interested in the canon and in the history of politics, though this also is within limits, since their focus is always inevitably on present power and practice. Only the sceptical political theorist acknowledges that history defeats most of the simplicities found in the other three forms of theory. 'The discontinuities apparent in human experience - between intention and consequence, ambition and accomplishment, knowledge of what it is right to do and capacity to do it - are not the result of verbal confusion, systematic error or incapacity to see the world for what it is. They are on the contrary limitations embedded in all human situations' (Cowling, 1963, p. 11). History makes us aware of the arbitrariness of our arguments, our beliefs, our ideologies, our traditions, even the canon itself.

Sceptical political theory is, as I have hinted, not incompatible with belief. It is only distinctively and independently political beliefs which are considered suspect. I would argue that sceptical political theory has a stronger awareness of the status 
of belief than any other form of theory. This is because of history again: the sceptical political theorist cannot leave anything out. He or she must recognise everything: high and low, superstitious and enthusiastic and enlightened, secular and religious, matters of law and justice. For this reason the sceptic is better able to understand religion. He or she is more inclined to recognise the need for religion as theoretical basis, the fact that secularisation conceals quasi-religious commitments, the fact that the reification of politics is itself a quasi-religious phenomenon. I would go so far as to say that sceptical political theory, though not possessing any intrinsic religious content, is far better able to make sense of the distinctively and decisively religious element in human thought and activity than any other form of political theory. This is not only because it demands scepticism about secularism and atheism and insists that we recognise the continued existence of historical religions on earth, but also because it supposes that most political theories are in fact fragments of religious positions. Schmitt said in 1922, 'All significant concepts of the modern theory of the state are secularised theological concepts not only because of their historical development... but also because of their systematic structure' (Schmitt, 2005, p. 36). Only sceptical political theory can do justice to what is now called 'political theology', to what Owen Chadwick called 'the secularisation of the European mind in the nineteenth century', and to the continued significance of religion everywhere (Taylor, 2007; Lilla, 2007; Allen, 2008).

It is difficult to say more about sceptical political theory because it does not yet exist, except, as I have suggested, in the interstices of what has been written in the last century. Nonetheless, some non-sceptical theorists have begun to see that it is necessary to argue against scepticism, though they have mostly done so by accusing it of quietism or pessimism. The theorists making these criticism have opposed such hopelessness with robust statements of hope (Pettit, 2004; Miller, 2013). As would be expected, such criticisms are unlikely to convince the sceptical political theorist, who would comment that at its greatest, political theory has contributed to the great conversation which comprises man's self-understanding. There is no reason why a sceptical political theorist should ever be an enthusiast for secular hope. The entire canon is a satire against such hope. So it is ironic that in the end the sceptical theorist is the theorist who has attempted to restore as much of the old canonical theory as possible, although in a modern, critical spirit.

The sceptical political theorist is someone who would say 'If you want to understand politics, study the history of politics', and 'If you want to understand theories of politics, read as much as you can - read historically about Greece and Rome, but also about India, China and Islam - and try to see how ideas have a history in relation to other ideas and have a tortured relationship with practice at all times, including now'. The point is that though there may be truth, it is unlikely to be found in politics or even about politics. If Heidegger was right and we are 'thrown' into the world, then politics is the way we 'throw' ourselves and each other into (and around) the world. Politics is, as Ankersmit (1996) has suggested, 
completely saturated in metaphors and symbols. Metaphors are, literally, things transferred; symbols are, literally, things thrown. Everywhere there are things standing for other things, and it is all we can do to make sense of the sense we make in politics, as we stand, throw and are thrown.

In sum, sceptical political theory claims that theory is not obviously of any identifiable causal significance, in either of two senses: firstly, because it does not suppose we can explain cause and consequence in politics, and, secondly, because the theory itself is unlikely to have clear political consequences. It takes politics to be what it is and nothing else, and so suggests that politics should be studied historically, while political theory should be studied not solely as but certainly in relation to the history of political theory. It considers that a calm and uncommitted attempt to understand politics is meaningful and cannot be abandoned simply because of a third way cliché that every theory comes out of politics. It has so far tended to find that theorising about politics is an activity of highly uncertain result, though it has a certain academic value. It is more mindful of the entire canon of political theorising than any of its rivals. And, as such, it may be the most worthy successor of the old canonical political theory.

\section{Conclusion}

A few years ago Andrew Rehfeld wrote an article entitled 'Offensive Political Theory' (Rehfeld, 2010). In it he asked which types of political theory should be included in political science. His answer was that conceptual, normative, explanatory and interpretive political theory should be included; but that advocacy should not be included (which excludes much of third way political theory), and also that history should not be included (which excludes much of sceptical political theory as well as the memory of the old canonical political theory). It should be obvious why I cannot agree with either of these exclusions - they would eliminate half of the forms of political theory as outlined here, and, arguably, more than half of what has made political theory of interest. I would like to point out that if the present article is rightly understood it should appear far more offensive than Rehfeld's article, since it is actually more critical about much of political theory than his is (even if it is more tolerant of its varieties).

In this article I have sketched a typology of four types of political theory and the genealogy by which they emerge in admittedly conjectural succession out of an original canonical form of theory. Since the strategy was genealogical, I have not so much argued for sceptical political theory as dramatise its necessity in terms of the story told. Indeed, this article itself is a consequence of the way of thinking I think is necessary.

What the genealogy has shown is that only the old canonical political theory no longer exists. It was destroyed in the early twentieth century, though its legacy 
remains in fractured form. We can see this legacy in the four types of political theory, all of which have practitioners active today. Positive political theorists still distinguish is and ought: they distinguish factual and normative claims and declare that only the first are the proper subject of political theory. Since canonical political theory did not make this distinction, positive political theorists think that 'much of political theory prior to the twentieth century is based on a mistake' (Frohock, 1974 , p. 8). Normative political theorists still accept that there is 'a logical distinction between normative and empirical statements' (Frohock, 1974, p. 20). But, unlike positive political theorists, they do not dismiss normative theory: on the contrary, they use the distinction to defend normative theory, drawing attention to the distinct contribution that it can make, in sketching an ideal polity, and in considering the ideals, values and principles which even positive political theorists take for granted. They accept the distinction of is and ought, and urge coexistence: there can be two types of political theory, one concerned with is and one concerned with ought. Third way political theorists are those who consider that the distinction is itself a problem. They say that all theory is dependent on prior commitments, which are not so much scientific or normative as themselves political. In addition, in saying this, they draw attention to the fact that positive and normative political theory often seem to be more concerned to understand something other than politics, or turn politics into something else, into something excessively rational or moral. Third way political theorists take commitment to be fundamental, though commitment may be to normative views or to something else. Though third way political theorists vary in how radical their view of politics and theory is, they should, I think, be classed together. Finally, sceptical political theorists are those who would agree that the distinction between is and ought is too simple. They would agree that politics is not to be reduced to something else. But they would not think commitment is fundamental (and certainly not any political commitment without some further fully theorised commitment): on the contrary, for them, understanding would remain fundamental, but would now be complicated by the possibility that understanding is continually threatened by commitment. The sceptical political theorist would hold on to an awareness of this above all else. Nor would they think action is fundamental. The theorist would only consider himself or herself entitled to contemplate politics. I expect most theorists will disagree with this genealogy. But it lays down the challenge to suggest a better one. Such a genealogy is necessary if we are to prevent political theory perpetuating its recent and arbitrary traditions without reflection.

The originality of the particular genealogy sketched in this article is that it attempts to see all forms of political theory as a successive sequence of types. The merits of this are threefold. One is that political theory is seen as a whole. The varieties of political theory in the twentieth century are seen as responses to the original separation of political science from the canon of classical political works. The distinction between what I call positive and normative political theory is well 
established. I claim no originality there. But a second merit is that the genealogy enables us to attempt to class what I call third way theories together for the first time and relate them to the first two types of theory, by indicating genealogically how they emerged from a concern about normative theory just as normative theory emerged out of a concern about positive political theory. A third merit is that I include a yet reticent fourth modern type: sceptical political theory. I have not characterised it in full here, but I contrast its assumptions with the others and indicate genealogically how it might be considered to have emerged out of a concern with third way political theory.

Sceptical political theory brings the genealogy to an end because it approaches politics with the same seriousness as the old canonical political theory, and yet without the solemnity and simplicities and solipsisms of the three major successor forms of classical political theory. It is capacious, like canonical political theory, but also sharp, like its rival types of modern political theory. It has a better sense of the strengths and weakness of the other types than they do. In addition, it may be the only form of political theory which has any claim to be an encouragement to wisdom.

I can imagine a political theorist on reading this article saying 'So what?' To answer this inevitable question: I do not suppose this article will assist political theorists in future by showing them how to continue mining out exhausted seams or building castles in the air. Instead I want political theorists to consider the possibility that what they have so far engaged in may be an arbitrary, limited and perhaps mistaken sort of study. This might be so; it might not be so. But it seems valuable, in an age in which there is always encouragement to do more research, to say that less should be done. Geuss recently asked whether criticism had to be constructive. His answer was that it did not (2014, p. 68). I agree. In a time in which the academic study of politics is proliferating, in which experts in one field of political theory are not familiar with the work of those in another, it seems to me to be a necessary function of one strand of political theory to declare itself critically on the value of certain scholarly and theoretical endeavours, and force others to think again about them. I myself would hope that an encounter with the genealogy sketched in this article would make it clear that part of the point is to put a question mark against positive, normative and third way political theories. They are, within their limits, of some interest: but they exist within limits which damage their capacity to say anything about politics. I think we should agree with Ankersmit (1996, p. 15) that the discipline which has most to tell us about the broken, discontinuous world of politics, full of irrelevance, inadvertence and ambition, has been neither political science nor political theory but history. 


\section{About the Author}

James Alexander teaches political theory in the Department of Political Science, Bilkent University, Ankara, Turkey. Some of his recent articles are The Fundamental Contradiction of Cosmopolitanism, European Legacy (2016), A Systematic Theory of Tradition, Journal of the Philosophy of History (2016), and Notes Towards a Definition of Politics, Philosophy (2014).

\section{Notes}

1 Sometimes rational choice theory is considered 'normative'. But I think it is fair to say that the ideals of rational choice theory are ideals of the is of politics rather than ideals of ought: that is to say, they do not tell us what we should aspire to; they tell us what we would do if our behaviour were maximally rational. It is scientific in that it attempts to tell us what is the case, not what ought morally, or legally to be the case.

2 The phrase 'third way' is probably still associated with the vague theoretical gesturings of Lord (Anthony) Giddens at the time of the election of Tony Blair and the arrival of 'New Labour' to power in 1997. The phrase is, of course, much older. I use it here because it indicates the reactionary nature of these theories: they are a reaction to the two antecedent forms of political theory and are so in such a way that they are mindful of their antecedents. It also suggests that they are in the nature of a compromise. Of course, these theories are united in attempting to relate theory to actual politics more effectively. Waldron (2013) has for this reason suggested the name 'political political theory', but this, besides being clumsy, is still rather unspecific, and does not indicate how dependent this form of political theory on the antecedent types. So, for the time being, at least, I use the term 'third way' as the name for this class of theories.

3 On pp. 81-82 ff. of this book Mouffe comes very close to outlining a theory of the first three types of theory that I sketch here (though her third, as we should expect, since she is a third way theorist, is only one variant of what I am calling a third way theory).

4 The names are meant to be illustrative only. I am not attempting characterisations of these admittedly difficult and ambiguous figures. The explanation of Geuss offered in note 5 below could be repeated in every case.

5 I sometimes doubt whether there is much difference. For instance, Žižek sounds very much like Honig or Mouffe when he says that 'the entire history of European political thought is ultimately nothing but a series of disavowals of the political moment, of the proper logic of political antagonism' (Žižek, 2007, p. 186). The problem with most of this radical literature is that it writes using a deliberately opaque style which is difficult to translate into the standard at least apparently transparent style of Anglo-American political theory (which I am obviously using here). Not much has yet been done to clarify matters. For a beginning, see Marchart, (2007).

6 Geuss, for instance, is an ambiguous figure. He is in part a sceptical political theorist, insisting that criticism does not have to be constructive (Geuss, 2014, pp. 68-90), and advocating 'genealogy', by which he means the 'historical dissolution of self-evident identities' (Geuss, 2005, p. 257). But he is also in part a third way political theorist, seeking to advance 'radical social criticism'. (Geuss, 2005, p. 1) Such ambiguities surround many political theorists, not always the most immediately influential, but certainly the most interesting. 


\section{References}

Adcock, R., Bevir, M. and Stimson, S.C. (Eds.) (2007) Modern Political Science: Anglo-American Exchanges. Princeton: Princeton University Press.

Allen, M.G. (2008) The Theological Origins of Modernity. Chicago: University of Chicago Press.

Almond, G. (1966) Political Theory and Political Science. The American Political Science Review, 60: 869-879.

Anderson, P. (2005) Designing Consensus: John Rawls. In P. Anderson (Ed.) Spectrum. London: Verso, pp. $103-112$

Ankersmit, F.R. (1996) Aesthetic Politics: Political Philosophy Beyond Fact and Value. Stanford: Stanford University Press.

Ashford E. and Mulgan, T. (2012) 'Contractualism'. The Stanford Encyclopaedia of Philosophy (Fall 2012 Edition). https://plato.stanford.edu/archives/fall2012/entries/contractualism/

Badiou, A. (2005) Metapolitics trans. Jason Barker. London: Verso.

Barry, B. (1990) Political Argument: A Reissue with a New Introduction. Berkeley: University of California Press.

Barry, B. (1996) Political Theory: Old and New. In R. E. Goodin and H.-D. Klingemann (Eds.) A New Handbook of Political Science. Oxford: Oxford University Press, p. 1996

Beiner, R. (2014) Political Philosophy: What It Is and Why It Matters. Cambridge: Cambridge University Press.

Berndtson, E. (1987) The Rise and Fall of American Political Science: Personalities, Quotations, Speculations. International Political Science Review, 8: 85-100.

Bevir, M. (2008) What is Genealogy? Journal of the Philosophy of History 2: 263-275.

Burrow, J.A. (1966) Evolution and Society: A Study in Victorian Social Theory. Cambridge: Cambridge University Press.

Collini, S., Winch, D. and Burrow, J. (Eds.) (1983) That Noble Science of Politics: A Study in Nineteenth-Century Intellectual History. Cambridge: Cambridge University Press.

Cowling, M. (1963) The Nature and Limits of Political Science. Cambridge: Cambridge University Press.

Cowling, M. (2001) Religion and Public Doctrine in Modern England, Vol. III. Cambridge: Cambridge University Press.

Dryzek, J., Honig, B. and Phillips, A. (2009) Overview of Political Theory. In Robert E. Goodin (Ed.) Oxford Handbook of Political Science. Oxford: Oxford University Press, pp. 61-88

Easton, D. (1991) Political Science in the United States. In D. Easton and C. Shelley (Eds.) Divided Knowledge: Across Disciplines, Across Cultures. Newbury Park, CA: Sage, pp. 37-58

Foucault, M. (2008) Two Lectures. In G. Burchell (Ed.) The Birth of Biopolitics: Lectures at the College de France 1978-79, trans. Graham Burchell. London: Palgrave Macmillan, pp. 267-316

Frohock, F.H. (1974) Normative Political Theory. Englewood Cliffs, NJ: Prentice-Hall.

Galston, W. (2010) Realism in Political Theory. European Journal of Political Theory 9: 385-411.

Geuss, R. (1999) Nietzsche and Genealogy. In R. Geuss (Ed.) Morality, Culture and History: Essays on German Philosophy. Cambridge: Cambridge University Press.

Geuss, R. (2005) Outside Ethics. Princeton: Princeton University Press.

Geuss, R. (2009). Philosophy and Real Politics. Princeton: Princeton University Press.

Geuss, R. (2014) A World Without Why. Princeton: Princeton University Press.

Grant, R.W. (2003) Political Theory, Political Science and Politics. Political Theory, 30: 577-595.

Green, D. P. and Shapiro, I. (1994) Pathologies of Rational Choice Theory: A Critique of Applications in Political Science. New Haven: Yale University Press.

Gunnell, J.G. (1987) Political Theory: Tradition and Interpretation. Lanham: University Press of America. 
Honig, B. (1993) Political Theory and the Displacement of Politics. Ithaca: Cornell University Press.

Kaufman-Osborn, T.V. (2010) Political Theory as Profession and as Subfield. Political Research Quarterly, 63: 655-673.

Kelly, P. (2005) Liberalism. Cambridge: Polity Press.

Knight, J. and Johnson, J. (2015) 'On Attempts to Gerrymander "Positive" and "Normative" Political Theory: Six Theses'. The Good Society, 24(1): 30-48.

Korsgaard, C. (1996) The Sources of Normativity. Cambridge: Cambridge University Press.

Kymlicka, W. (2002) Contemporary Political Philosophy: An Introduction (2nd ed.). Oxford: Oxford University Press.

Lane, M. (2012) Doing Our Own Thinking for Ourselves: On Quentin Skinner's Genealogical Turn. Journal of the History of Ideas, 73: 71-82.

Lilla, M. (2007) The Stillborn God: Religion, Politics and the Modern West. New York: Vintage Books.

Marchart, O. (2007) Post-Foundational Political Thought: Political Difference in Nancy, Lefort, Badiou and Laclau. Edinburgh: Edinburgh University Press.

Miller, D. (2013) A Tale of Two Cities; or, Political Philosophy as Lamentation. In D. Miller (Ed.) Justice for Earthlings: Essays in Political Philosophy. Cambridge: Cambridge University Press, pp. 228-249

Morgenthau, H.J. (1955) Reflections on the State of Political Science. The Review of Politics, 17: 431-460.

Mouffe, C. (2005) The Democratic Paradox. London: Verso.

Nehemas, A. (1985) Nietzsche: Life as Literature. Cambridge, MA: Harvard University Press.

Oakeshott, M. (1999) On History and Other Essays. Indianapolis: Liberty Fund.

Oakeshott, M. (2004) What is Political Theory? In M. Oakeshott (Ed.) What is History? And Other Essays. Exeter: Imprint Academic, pp. 391-402.

Pettit, P. (2004) Existentialism, Quietism and the Role of Philosophy. In B. Leiter (Ed.) The Future for Philosophy. Oxford: Clarendon Press, pp. 304-327

Rawls, J. (2001) In E. Kelly (Ed.), Justice as Fairness: A Restatement. Cambridge, MA: Belknap Press.

Rehfeld, A. (2010) Offensive Political Theory. Perspectives on Politics, 8: 465-486.

Ricci, D. (1984) The Tragedy of Political Science: Politics, Scholarship and Democracy. New Haven: Yale University Press.

Sandel, M. (1982) Liberalism and the Limits of Justice. Cambridge: Cambridge University Press.

Schmitt, C. (2005) Political Theology: Four Chapters on the Concept of Sovereignty, trans. George Schwab. Chicago: University of Chicago Press.

Swift, A. (2013) Political Philosophy: A Beginner's Guide for Students and Politicians (3rd ed.). Cambridge: Polity Press.

Taylor, C. (2007) A Secular Age. Cambridge, MA: Belknap Press.

Waldron, J. (2013) Political Political Theory: An Inaugural Lecture. Journal of Political Philosophy, 21: $1-23$.

Wolff, J. (2015) An Introduction to Political Philosophy (3rd ed.). Oxford: Oxford University Press.

Wolin, S. (1969) Political Theory as a Vocation. American Political Science Review, 63: 1062-1082.

Žižek, S. (2007) A Leftist Plea for Eurocentrism. In S. Zizek (Ed.) The Universal Exception. London: Verso, pp. 183-207

Žižek, S. (2014) Event: Philosophy in Transit. London: Penguin. 